\title{
Covid-19: Papers justifying government's plans to reopen schools are "inconclusive," say union bosses
}

\author{
Adrian O'Dowd
}

London

Several documents presented to the UK government from its scientific advisers analysing how and when it may be safe to reopen schools in England on 1 June have now been released after pressure from experts and trade unions. However, the papers have not reassured unions and experts about the wisdom of the timetable and have been described as containing "inconclusive" evidence.

The government's advisory body, the Scientific Advisory Group for Emergencies (SAGE), has produced several documents ${ }^{1}$ looking at various scenarios or "options" for relaxing school closures that were implemented in March because of the coronavirus.

One of these documents says, "There is substantial uncertainty, with the relative contribution of school openings being driven also by the relative susceptibility and infectivity of children of different ages compared to adults, as well as the extent to which social distancing is or is not sustained in the wider population." Collectively, the documents led to the government announcing on 10 May that, from 1 June, primary schools should welcome back children in reception, year 1, and year 6 , while nurseries and other early years providers should begin welcoming back children of all ages.

From 15 June secondary schools, sixth forms, and colleges should also provide face-to-face contact for year 10, year 12, and equivalent 16-19 further education students to help them prepare for exams next year.

However, the recently created Independent Scientific Advisory Group for Emergencies (iSAGE) has questioned the approach and released its own draft report, ${ }^{2}$ which concludes that schools should not reopen on 1 June because of "no clear evidence" that it is safe to do so when local "test, track, and isolate" systems are not yet in place.

\section{"Dangerous decision"}

The iSAGE report says that delaying school reopening by two weeks would halve the risk to children and that, before reopening schools, local authorities should establish low levels of infection in the community and have the ability to track, trace, and isolate new infections.
During a public engagement session held on 22 May in association with The BMJ and the online forum Mumsnet and broadcast live on YouTube, ${ }^{3}$ iSAGE's committee chair, David King, called on SAGE to publish all of its documentation and minutes that had led to the government's approach to reopening schools. SAGE has now done so, but this has not greatly changed opinion among people who are concerned.

King said, "It is clear from the evidence we have collected that 1 June is simply too early to go back. By going ahead with this dangerous decision, the government is further risking the health of our communities and the likelihood of a second spike."

Patrick Roach, general secretary of the NASUWT teachers' union, said, "The prime minister's display of determination to press ahead with the wider reopening of schools from 1 June is seriously at odds with the scientific evidence released to date, and the deep concerns expressed by schools, teachers, and parents.

"The prime minister has rightly stressed the importance of bringing down the $\mathrm{R}$ [reproduction] rate below 1, but the evidence published to date by SAGE is inconclusive when it comes to the question of whether the wider reopening of schools could contribute to a second wave of covid-19 infections."

Geoff Barton, general secretary of the Association of School and College Leaders, said, "We are pleased the government has published this scientific evidence. It will quickly become clear to anybody reading the papers that the science is not definitive, and indeed, it cannot be in a situation where we are dealing with a new virus which is not fully understood."

1 Gov.uk. Scientific Advisory Group for Emergencies (SAGE): Coronavirus (COVID-19) response. 2020. https://www.gov.uk/government/groups/scientific-advisory-group-foremergencies-sage-coronavirus-covid-19-response.

2 Independent SAGE. Should schools reopen? Draft document for public discussion. May 2020. www.independentsage.org/read-the-independent-sage-report-on-schools.

3 Wise J. Covid-19: Delaying school reopening by two weeks would halve risks to children, says iSAGE. BMJ 2020;369:m2079. 10.1136/bmj.m2079 32444387

This article is made freely available for use in accordance with BMJ's website terms and conditions for the duration of the covid-19 pandemic or until otherwise determined by BMJ. You may use, download and print the article for any lawful, non-commercial purpose (including text and data mining) provided that all copyright notices and trade marks are retained.

https://bmj.com/coronavirus/usage 